\title{
Horizontes de planificación diferentes. Una discusión necesaria
}

\author{
Gustavo Pérez \\ Profesor Titular FIQ-FBCB, UNL \\ Email: gus@santafe-conicet.gov.ar
}

\author{
José Medina \\ Profesor Adjunto, FIQ, UNL \\ Email: jrmedina@fiq.unl.edu.ar
}

Palabras clave

- Decisiones económicas

- Ciclo de vida del proyecto

- Costo anual equivalente

\section{Resumen}

El horizonte de planificación, o ciclo de vida del proyecto, es una importante variable independiente, tanto como la tasa de descuento elegida, usual en todos los métodos de flujo de fondos descontados, siendo su elección fuertemente dependiente del caso específico tratado. La comparación entre inversiones que tienen vidas diferentes es un tema complicado. La mayoría de los métodos hallados en la literatura tienen hipótesis que, 0 no son totalmente claras, o no guardan el necesario rigor, a causa del problema siempre presente de la consideración de repetitividad. En este trabajo se concluye que el conocido método del beneficio (o costo) anual equivalente es una buena opción, y su defensa se basa en la simplicidad y el uso universal que se le ha dado al mismo. Por otra parte, también, se ha propuesto otra alternativa para llevar adelante esta tarea de decisión, como una contribución más a la cuestión aquí planteada.

\footnotetext{
Abstract

Project life cycle is an important independent variable, as the discounted rate-namely, cost of capital, for the ussual discounted cash flow method - and its choice is strongly dependent on the specific investment- Comparison of projects with unequal lives is a particularly troublesome issue. Many of the methods —or almost of them — have underlying assumptions that are not always clearly stated, or without the necessary robustness, because the repeatability consideration. In this work, the major conclusion is the annual equivalence benefit (or cost) defense, in the sake of it simplicity and universal application. Furthermore, the authors propose another way to carry out this decision making task.
}

Keywords - Economic decisions - Project life cycle - Equivalent annual cost 